\title{
Observations of Birds in the East China Sea, April 1968, "Umitaka Maru”
}

\author{
Keijiro Ozawa* \\ Introduction
}

The training ship "Umitaka Maru" of the Tokyo University of Fisheries cruised in the East China Sea in April 1968. During the cruise the author and ship's staffs including students stationed at the navigation bridge kept bird-watching, recording the data on "Visual Observation Log". The area where the observations were carried out is shown in Fig. 1. Location of the ship's positions at every four hours and the track drawn by connecting each point is mapped in Fig. 2.

The area dealt with in this paper is limited within geographical lines bounded

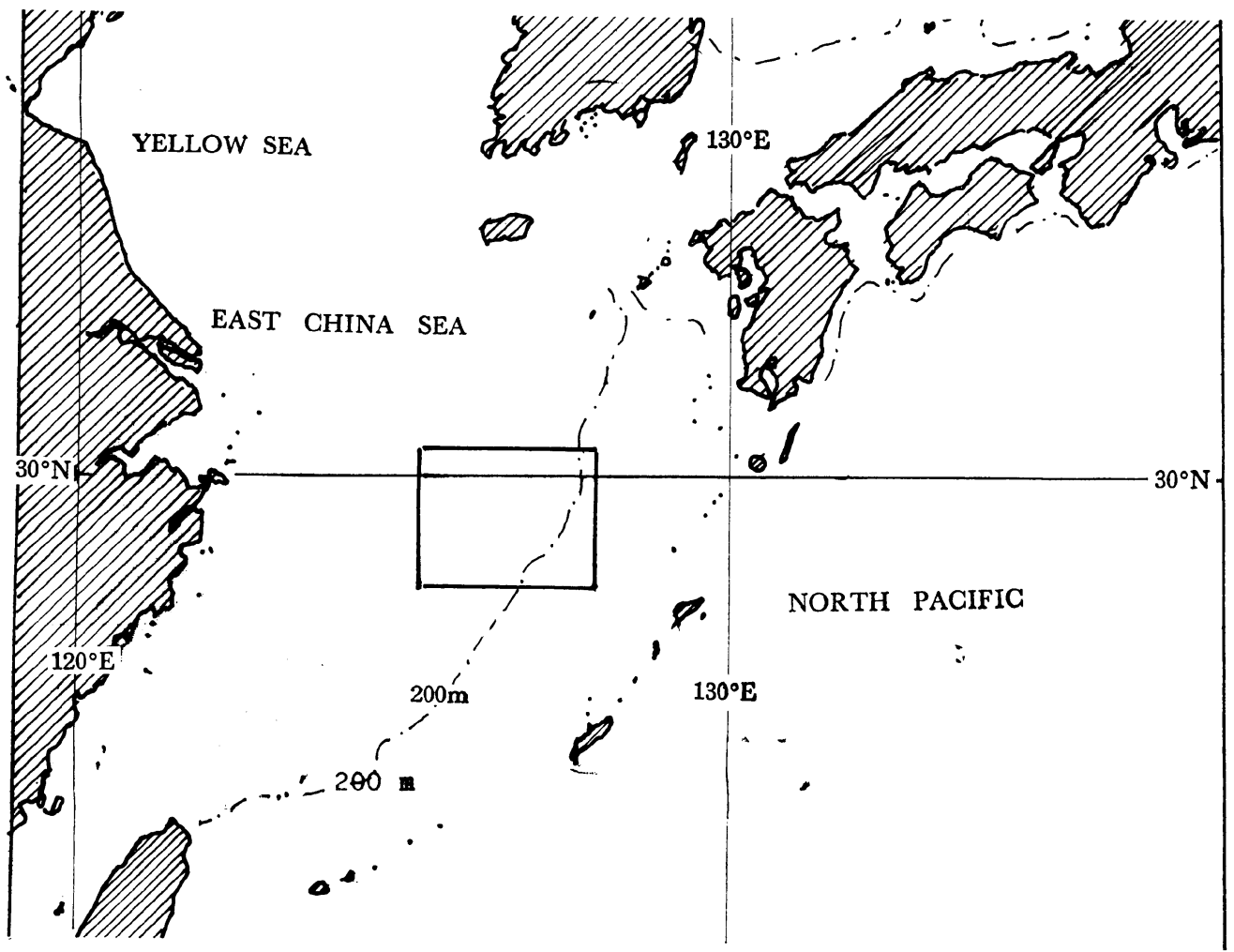

Fig. 1. Position of the observation area in the East China Sea, shown by square.

\footnotetext{
* Umitaka Maru, Tokyo University of Fisheries
} 


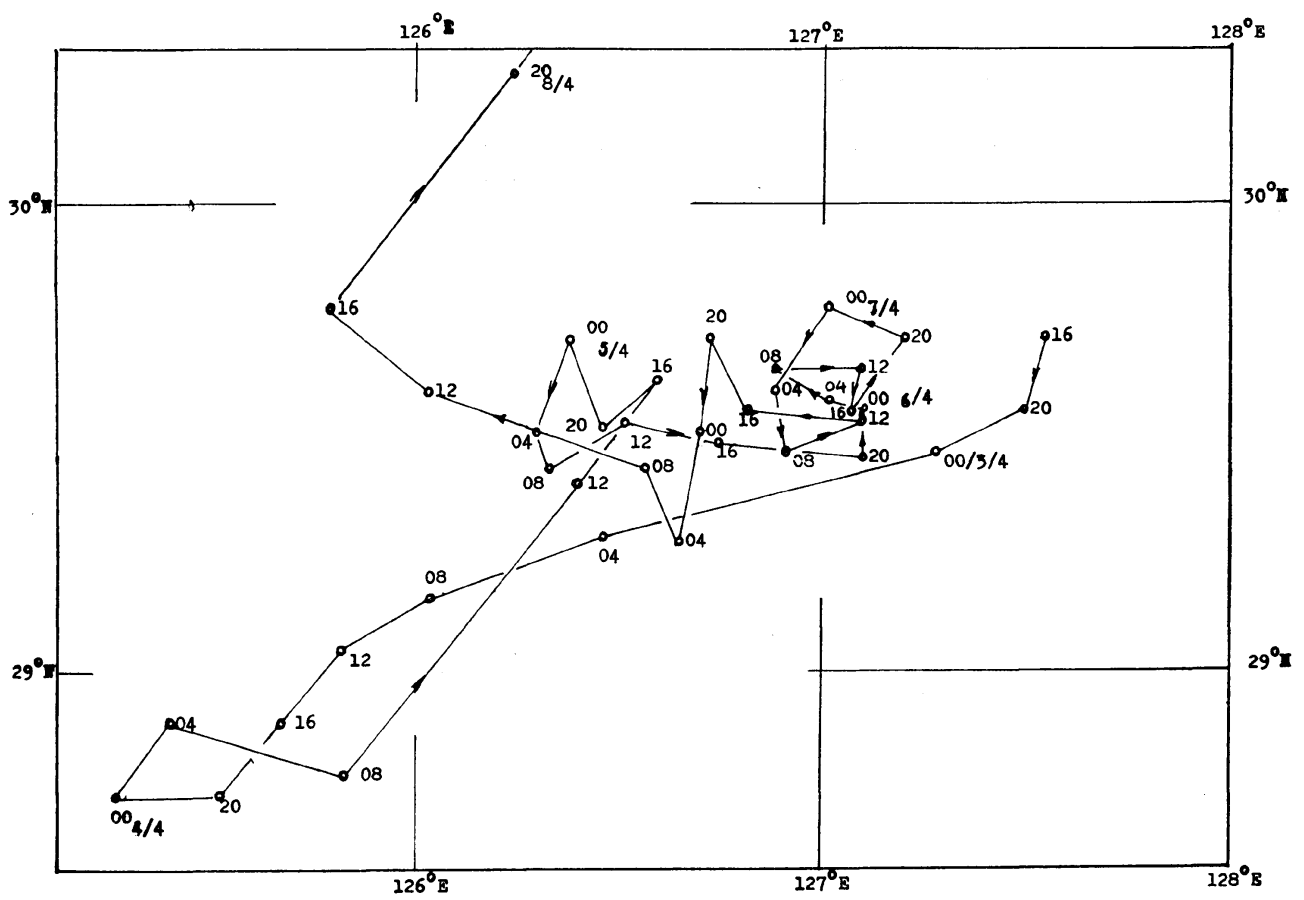

Fig. 2. Map showing locations of ship's positions every four hours in the area indicated in Fig. 1.

by latitudes $30^{\circ} 15^{\prime}-28^{\circ} 40^{\prime} \mathrm{N}$ and longitudes $125^{\circ}-128^{\circ} \mathrm{E}$. The region is located approximately at a midway between the "Nansei" Islands, including Amami-Oshima and Okinawa, and the Chinese coast, nearly 200 miles to each, and also some 250 miles to Kyushu as well as Formosa.

In April, there were found not only sea-birds but also land-birds migrating northwards from their wintering grounds in Borneo, Malaya, Philippines, etc. However, the records of land-birds at sea in this season may not necessarily reveal their regular migration routes.

The scientific and common names of the species sighted are as follows; the English names are used throughout this paper.

Sea-birds :

Calonectris leucomelas

Puffinus carneipes

Phalaropus lobatus

Stercorarius pomarinus

Larus sp.

Land-birds :

Motacilla alba lugens

M. cinerea caspica

Turdus pallidus

Troglodytes troglodytes

Hirundo rustica
Streaked Shearwater Pink-footed Shearwater Red-necked Phalarope Pomarine Skua Gull

Pied Wagtail

Gray Wagtail

Pale Ouzel

Wren

House Swallow

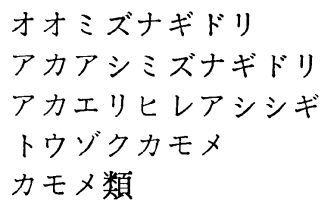


The paper reports general results of the observations, particularly referring to distributions of Streaked Shearwater and Red-necked Phalarope in relation with oceanographical conditions, as well as occurrence of House Swallows in relation to weather conditions, etc.

The author would like to express thanks to the officers and quartermasters of the ship for their positive efforts. The author is also grateful to Dr. N. Kuroda of the Yamashina Institute of Ornithology for his helpful suggetions and a critical reading of this manuscript.

1. Brief notes of the observations.

Summarized records of the observatios are tabulated in Table 1, which includes bird data, time, position, weather condition, wind direction and its force in the Beaufort scale, barometric height, air and sea temperatures at every four hours. The observation freqency is given by total numbers of half-hourly sightings and

Table 1. Summarized records of bird observations in the East China Sea, April 2-8, 1968

\begin{tabular}{|c|c|c|c|c|c|c|c|c|c|c|c|}
\hline \multirow{3}{*}{$\begin{array}{l}\text { Date } \\
\text { Time } \\
\text { April }\end{array}$} & \multirow{3}{*}{$\begin{array}{c}\text { Position } \\
\text { Lat. } \\
\text { Long. }\end{array}$} & \multirow{3}{*}{$\mathrm{Wr}$} & \multirow{2}{*}{\multicolumn{2}{|c|}{$\begin{array}{l}\text { Wind } \\
\text { Dir. } \\
\text { Force }\end{array}$}} & \multirow{3}{*}{$\begin{array}{l}\text { Baro. } \\
\text { (mb) }\end{array}$} & \multirow{3}{*}{$\begin{array}{c}\text { Temp. } \\
\text { air } \\
\text { sea } \\
\left({ }^{\circ} \mathrm{C}\right) \\
\end{array}$} & \multirow{3}{*}{$\begin{array}{l}\text { Obsed } \\
\text { freq. }\end{array}$} & \multicolumn{4}{|c|}{ Numbers tallied } \\
\hline & & & & & & & & \multicolumn{3}{|c|}{$\begin{array}{l}\text { C. } l . \mid \underset{\text { half-hourly- }}{\text { P. }} \text { - H. } \\
\end{array}$} & \multirow[t]{2}{*}{ Others } \\
\hline & & & & & & & & & & & \\
\hline 1600 & $\begin{array}{r}29^{\circ} 41^{\prime} \mathrm{N} \\
127^{\circ} 33^{\prime} \mathrm{E}\end{array}$ & o & $\mathrm{NE}$ & 3 & 1018.6 & $\begin{array}{r}18.6 \\
18.3\end{array}$ & 7 & 58 & 0 & 1 & P. c. 2 \\
\hline 2000 & $\begin{array}{r}29^{\circ} 32^{\prime} \mathrm{N} \\
127^{\circ} 28^{\prime} \mathrm{E}\end{array}$ & o & $\mathrm{E}$ & 2 & 1019.0 & $\begin{array}{c}19.0 \\
18.3\end{array}$ & - & & & & \\
\hline \multicolumn{12}{|c|}{ April 3} \\
\hline 0000 & $\begin{array}{r}29^{\circ} 27^{\prime} \mathrm{N} \\
127^{\circ} 16^{\prime} \mathrm{E}\end{array}$ & o & $\mathrm{NE} / \mathrm{E}$ & 1 & 1019.3 & $\begin{array}{r}18.4 \\
17.9\end{array}$ & - & & & & \\
\hline 0400 & $\begin{array}{r}29^{\circ} 16^{\prime} \mathrm{N} \\
126^{\circ} 26^{\prime} \mathrm{E}\end{array}$ & $\mathbf{r}$ & $\mathrm{N} / \mathrm{E}$ & 2 & 1018.3 & $\begin{array}{c}17.2 \\
16.7\end{array}$ & - & & & & \\
\hline 0800 & $\begin{array}{r}29^{\circ} 08^{\prime} \mathrm{N} \\
126^{\circ} 01^{\prime} \mathrm{E}\end{array}$ & o & NE & 3 & 1018. 2 & $\begin{array}{r}15.3 \\
15.5\end{array}$ & 2 & 0 & 0 & 7 & M.a.1, T.p.1 \\
\hline 1200 & $\begin{array}{r}29^{\circ} 02^{\prime} \mathrm{N} \\
125^{\circ} 49^{\prime} \mathrm{E}\end{array}$ & o & NNE & 4 & 1017.8 & $\begin{array}{l}15.1 \\
16.1\end{array}$ & 5 & 1 & 220 & 8 & \\
\hline 1600 & $\begin{array}{r}28^{\circ} 52^{\prime} \mathrm{N} \\
125^{\circ} 40^{\prime} \mathrm{E}\end{array}$ & o & $\mathrm{N} / \mathrm{W}$ & 4 & 1017.1 & $\begin{array}{l}15.1 \\
16.1\end{array}$ & 8 & 0 & 0 & 17 & S. p. 1 \\
\hline 2000 & $28^{\circ} 43^{\prime} \mathrm{N}$ & c & $\mathrm{N}$ & 3 & 1018. 1 & $\begin{array}{r}15.2 \\
16.9\end{array}$ & 3 & 0 & 0 & 10 & \\
\hline \multicolumn{12}{|c|}{ April 4} \\
\hline 0000 & $\begin{array}{r}28^{\circ} 42^{\prime} \mathrm{N} \\
125^{\circ} 15^{\prime} \mathrm{E}\end{array}$ & bc & $\mathrm{N}$ & 4 & 1019.0 & $\begin{array}{r}14.2 \\
14.7\end{array}$ & - & - & 一 & - & \\
\hline 0400 & $\begin{array}{r}28^{\circ} 52^{\prime} \mathrm{N} \\
125^{\circ} 24^{\prime} \mathrm{E}\end{array}$ & b & NNW & 4 & 1018.0 & $\begin{array}{c}13.9 \\
16.6\end{array}$ & - & - & - & - & \\
\hline 0800 & $\begin{array}{r}28^{\circ} 45^{\prime} \mathrm{N} \\
125^{\circ} 50^{\prime} \mathrm{E}\end{array}$ & c & $\mathrm{N}$ & 4 & 1018. 2 & $\begin{array}{r}14.2 \\
15.9\end{array}$ & 6 & 2 & 180 & 0 & M.c. 1 \\
\hline 1200 & $\begin{array}{r}29^{\circ} 23^{\prime} \mathrm{N} \\
126^{\circ} 24^{\prime} \mathrm{E}\end{array}$ & bc & NNW & 4 & 1020.0 & $\begin{array}{c}14.8 \\
16.4\end{array}$ & 8 & 0 & 46 & 0 & \\
\hline 1600 & $\begin{array}{r}29^{\circ} 37^{\prime} \mathrm{N} \\
126^{\circ} 35^{\prime} \mathrm{E}\end{array}$ & bc & $\mathrm{N} / \mathrm{W}$ & 3 & 1019.0 & $\begin{array}{r}15.2 \\
17.7\end{array}$ & 8 & 0 & 20 & 2 & \\
\hline 2000 & $\begin{array}{r}29^{\circ} 30^{\prime} \mathrm{N} \\
126^{\circ} 28^{\prime} \mathrm{E} \\
\end{array}$ & b & NNW & 4 & 1020.8 & $\begin{array}{c}14.0 \\
16.7\end{array}$ & 2 & 0 & 0 & 2 & \\
\hline
\end{tabular}




\begin{tabular}{|c|c|c|c|c|c|c|c|c|c|c|c|}
\hline \multirow{2}{*}{$\begin{array}{l}\text { Date } \\
\text { Time }\end{array}$} & \multirow{2}{*}{$\begin{array}{c}\text { Position } \\
\text { Lat. } \\
\text { Long. }\end{array}$} & \multirow{2}{*}{$\mathrm{Wr}$} & \multirow{2}{*}{\multicolumn{2}{|c|}{$\begin{array}{l}\text { Wind } \\
\text { Dir. } \\
\text { Force }\end{array}$}} & \multirow{2}{*}{$\begin{array}{l}\text { Baro. } \\
(\mathrm{mb})\end{array}$} & \multirow{2}{*}{$\begin{array}{c}\text { Temp. } \\
\text { air } \\
\text { sea } \\
\left({ }^{\circ} \mathrm{C}\right) \\
\end{array}$} & \multirow{3}{*}{$\begin{array}{l}\text { Obsed } \\
\text { freq. }\end{array}$} & \multicolumn{4}{|c|}{ Numbers tallied } \\
\hline & & & & & & & & \multicolumn{3}{|c|}{$\begin{array}{c}\text { C.p.|P.l. } P \text { H. } \\
\text {-half-hourly- }\end{array}$} & Others \\
\hline \multicolumn{11}{|c|}{ April 5} & \\
\hline 0000 & $\begin{array}{r}29^{\circ} 41^{\prime} \mathrm{N} \\
126^{\circ} 23^{\prime} \mathrm{E}\end{array}$ & $\mathrm{b}$ & $\mathrm{N}$ & 3 & 1021.3 & $\begin{array}{l}12.8 \\
14.2\end{array}$ & - & - & - & - & \\
\hline 0400 & $\begin{array}{r}29^{\circ} 29^{\prime} \mathrm{N} \\
126^{\circ} 18^{\prime} \mathrm{E}\end{array}$ & $\mathrm{b}$ & W & 1 & 1020.5 & $\begin{array}{c}12.8 \\
14.8\end{array}$ & - & - & - & - & \\
\hline 0800 & $\begin{array}{r}29^{\circ} 26^{\prime} \mathrm{N} \\
126^{\circ} 19^{\prime} \mathrm{E}\end{array}$ & $\mathrm{b}$ & $\mathrm{NE}$ & 2 & 1022.8 & $\begin{array}{c}13.8 \\
15.5\end{array}$ & 8 & 0 & 0 & 9 & \\
\hline 1200 & $\begin{array}{r}29^{\circ} 32^{\prime} \mathrm{N} \\
126^{\circ} 31^{\prime} \mathrm{E}\end{array}$ & b & $\mathrm{N}$ & 3 & 1023.4 & $\begin{array}{c}14.9 \\
16.9\end{array}$ & 8 & 0 & 50 & 8 & Gull 4 \\
\hline 1600 & $\begin{array}{r}29^{\circ} 29^{\prime} \mathrm{N} \\
126^{\circ} 45^{\prime} \mathrm{E}\end{array}$ & $\mathrm{b}$ & $\mathrm{N}$ & 2 & 1021.3 & $\begin{array}{c}15.2 \\
17.7\end{array}$ & 8 & 3 & 0 & 4 & \\
\hline 2000 & $\begin{array}{r}29^{\circ} 28^{\prime} \mathrm{N} \\
127^{\circ} 07^{\prime} \mathrm{E}\end{array}$ & $\mathrm{b}$ & NNE & 1 & 1021.1 & $\begin{array}{c}16.8 \\
17.6\end{array}$ & 2 & 0 & 0 & 0 & \\
\hline \multicolumn{12}{|c|}{ April 6} \\
\hline 0000 & $\begin{array}{r}29^{\circ} 32^{\prime} \mathrm{N} \\
127^{\circ} 06^{\prime} \mathrm{E}\end{array}$ & $\mathrm{b}$ & $\mathrm{N}$ & 2 & 1022.6 & $\begin{array}{r}16.2 \\
18.3\end{array}$ & - & & & & \\
\hline 0400 & $\begin{array}{r}29^{\circ} 35^{\prime} \mathrm{N} \\
127^{\circ} 02^{\prime} \mathrm{E}\end{array}$ & $\mathrm{b}$ & $\mathrm{N}$ & 2 & 1022.1 & $\begin{array}{c}16.1 \\
16.9\end{array}$ & - & & & & \\
\hline 0800 & $\begin{array}{r}29^{\circ} 38^{\prime} \mathrm{N} \\
126^{\circ} 54^{\prime} \mathrm{E}\end{array}$ & $\mathrm{b}$ & $\mathrm{NE}$ & 3 & 1023.6 & $\begin{array}{c}16.9 \\
17.7\end{array}$ & 7 & 151 & 60 & 4 & M. a. 1 \\
\hline 1200 & $\begin{array}{r}29^{\circ} 36^{\prime} \mathrm{N} \\
127^{\circ} 06^{\prime} \mathrm{E}\end{array}$ & $\mathrm{b}$ & $\mathrm{E}$ & 3 & 1024.1 & $\begin{array}{c}18.7 \\
18.5\end{array}$ & 7 & 41 & 0 & 5 & $\begin{array}{l}\text { M.c. } 2 \\
\text { T.t. } 2\end{array}$ \\
\hline 1600 & $\begin{array}{r}29^{\circ} 32^{\prime} \mathrm{N} \\
127^{\circ} 05^{\prime} \mathrm{E}\end{array}$ & $\mathrm{b}$ & $\mathrm{E}$ & 4 & 1022.5 & $\begin{array}{r}18.8 \\
18.8\end{array}$ & 8 & 65 & 0 & 5 & \\
\hline 2000 & $\begin{array}{r}29^{\circ} 42^{\prime} \mathrm{N} \\
127^{\circ} 12^{\prime} \mathrm{E}\end{array}$ & b & ESE & 4 & 1023.7 & $\begin{array}{c}18.2 \\
18.3\end{array}$ & 2 & 15 & 2 & 0 & \\
\hline \multicolumn{12}{|c|}{ April 7} \\
\hline 0000 & $\begin{array}{r}29^{\circ} 47^{\prime} \mathrm{N} \\
127^{\circ} 00^{\prime} \mathrm{E}\end{array}$ & c & $\mathrm{E} / \mathrm{S}$ & 2 & 1024.2 & $\begin{array}{r}18.4 \\
17.6\end{array}$ & - & & & & \\
\hline 0400 & $\begin{array}{r}29^{\circ} 36^{\prime} \mathrm{N} \\
126^{\circ} 53^{\prime} \mathrm{E}\end{array}$ & o & ESE & 2 & 1022.7 & $\begin{array}{c}18.4 \\
17.8\end{array}$ & - & & & & P. c. 1 \\
\hline 0800 & $\begin{array}{r}29^{\circ} 28^{\prime} \mathrm{N} \\
126^{\circ} 55^{\prime} \mathrm{E}\end{array}$ & o & $\mathrm{SE}$ & 3 & 1024.7 & $\begin{array}{c}18.7 \\
17.7\end{array}$ & 8 & 38 & 20 & 50 & $S . p .1$ \\
\hline 1200 & $\begin{array}{r}29^{\circ} 30^{\prime} \mathrm{N} \\
127^{\circ} 06^{\prime} \mathrm{E}\end{array}$ & o & SE & 2 & 1025.0 & $\begin{array}{c}19.4 \\
18.4\end{array}$ & 8 & 187 & 0 & 1 & M. a. 1 \\
\hline 1600 & $\begin{array}{r}29^{\circ} 33^{\prime} \mathrm{N} \\
126^{\circ} 50^{\prime} \mathrm{E}\end{array}$ & c & ESE & 3 & 1023.1 & $\begin{array}{c}19.3 \\
18.4\end{array}$ & 8 & 99 & 0 & 3 & T. t. 3 \\
\hline 2000 & $\begin{array}{r}20^{\circ} 41^{\prime} \mathrm{N} \\
126^{\circ} 43^{\prime} \mathrm{E}\end{array}$ & o & SE & 2 & 1023.5 & $\begin{array}{c}18.7 \\
17.4\end{array}$ & 2 & 25 & 10 & 0 & \\
\hline \multicolumn{12}{|c|}{ April 8} \\
\hline 0000 & $\begin{array}{r}29^{\circ} 28^{\prime} \mathrm{N} \\
125^{\circ} 41^{\prime} \mathrm{E}\end{array}$ & c & $\mathrm{SE}$ & 3 & 1024.0 & $\begin{array}{r}18.9 \\
17.4\end{array}$ & - & & & & \\
\hline 0400 & $\begin{array}{r}29^{\circ} 16^{\prime} \mathrm{N} \\
125^{\circ} 38^{\prime} \mathrm{E}\end{array}$ & c & $\mathrm{SE} / \mathrm{E}$ & 4 & 1022.4 & $\begin{array}{r}19.3 \\
17.6\end{array}$ & - & & & & \\
\hline 0800 & $\begin{array}{r}29^{\circ} 25^{\prime} \mathrm{N} \\
125^{\circ} 33^{\prime} \mathrm{E}\end{array}$ & bc & $\mathrm{SE}$ & 4 & 1021.9 & $\begin{array}{c}18.8 \\
17.3\end{array}$ & 7 & 68 & 50 & 0 & P.c. 1 \\
\hline 1200 & $\begin{array}{r}29^{\circ} 36^{\prime} \mathrm{N} \\
125^{\circ} 02^{\prime} \mathrm{E}\end{array}$ & bc & SSE & 4 & 1020.5 & $\begin{array}{r}18.0 \\
16.3\end{array}$ & 8 & 8 & 45 & 0 & \\
\hline 1600 & $\begin{array}{r}29^{\circ} 36^{\prime} \mathrm{N} \\
125^{\circ} 47^{\prime} \mathrm{E}\end{array}$ & bc & SSE & 3 & 1019.0 & $\begin{array}{c}17.2 \\
13.8\end{array}$ & 8 & 1 & 298 & 0 & \\
\hline 2000 & $\begin{array}{r}30^{\circ} 15^{\prime} \mathrm{N} \\
126^{\circ} 16^{\prime} \mathrm{E} \\
\end{array}$ & o & $\mathrm{S}$ & 4 & 1020.0 & $\begin{array}{r}16.0 \\
13.8 \\
\end{array}$ & 2 & 0 & 50 & 0 & \\
\hline & & & & & $\begin{array}{l}\text { Total } \\
\text { Numbe }\end{array}$ & irhtin & 150 & $\begin{array}{l}762 \\
5 .\end{array}$ & 7. & $\begin{array}{l}135 \\
0.9\end{array}$ & \\
\hline
\end{tabular}

Notes: Numbers were tallied half-hourly within two hours before and after the time, "1200" covered between $1000 \mathrm{hrs}$ and $1330 \mathrm{hrs}$

Abbriviations of species in the table are:C.l. (Clonectris leucomelas), P.l. (Phalaropus lobatas), P.c. (Puffinus carneipes), S. p. (Stercorarius pomarinus), H.r. (Hirundo rustica), M.a. (Motacilla alba), M.c. (M. cinerea), T.t. (Troglodytes troglodytes), T.p. (Turdus pallidus). 
the numbers of major species, i. e., Streaked Shearwater, Red-necked Phalarope and House Swallow are tallied, with notes on occasional other species of both seaand land-birds in the last column.

During our stay in these waters from April 2 to 8, 1968, a total of 150 sightings were made, and 1,051 Red-necked Phalaropes, 762 Streaked Shearwaters and 136 House Swallows were counted. A total of 4 Pink-footed Shearwaters were found mixed with Streaked Shearwaters and 3 Pomarine Skuas appeared. Gulls in young plumaged were once sighted. Location of occurrence of land-birds except House Swallow is mapped in Fig. 8.

As shown in Table 1, 3 Pied Wagtails, 3 Gray Wagtails, 4 Wrens and a single Pale Ouzel came into the observation.

2. Distributions of Streaked Sheawater and Red-necked Phalarope in relation to the surface temperature.

The Streaked Sheawater is an endemic species around Japan, wintering in the waters of the southern Japan, but migrates as far south as north of New Guinea in the equatorial Pacific, returning to the breeding islands in March. As mentioned previously a total of 762 birds were recorded. Fig. 3 shows the distribution of surface temperatures, and indicates a cold water mass of the Yellow Sea above the continental shelf extending eastward, and on the other hand, the western margin of the Kuroshio (Japan Current) stretching north-north-eastward to make a mixing boundary with the former. A warm water of more than $16^{\circ} \mathrm{C}$ penetrated into the

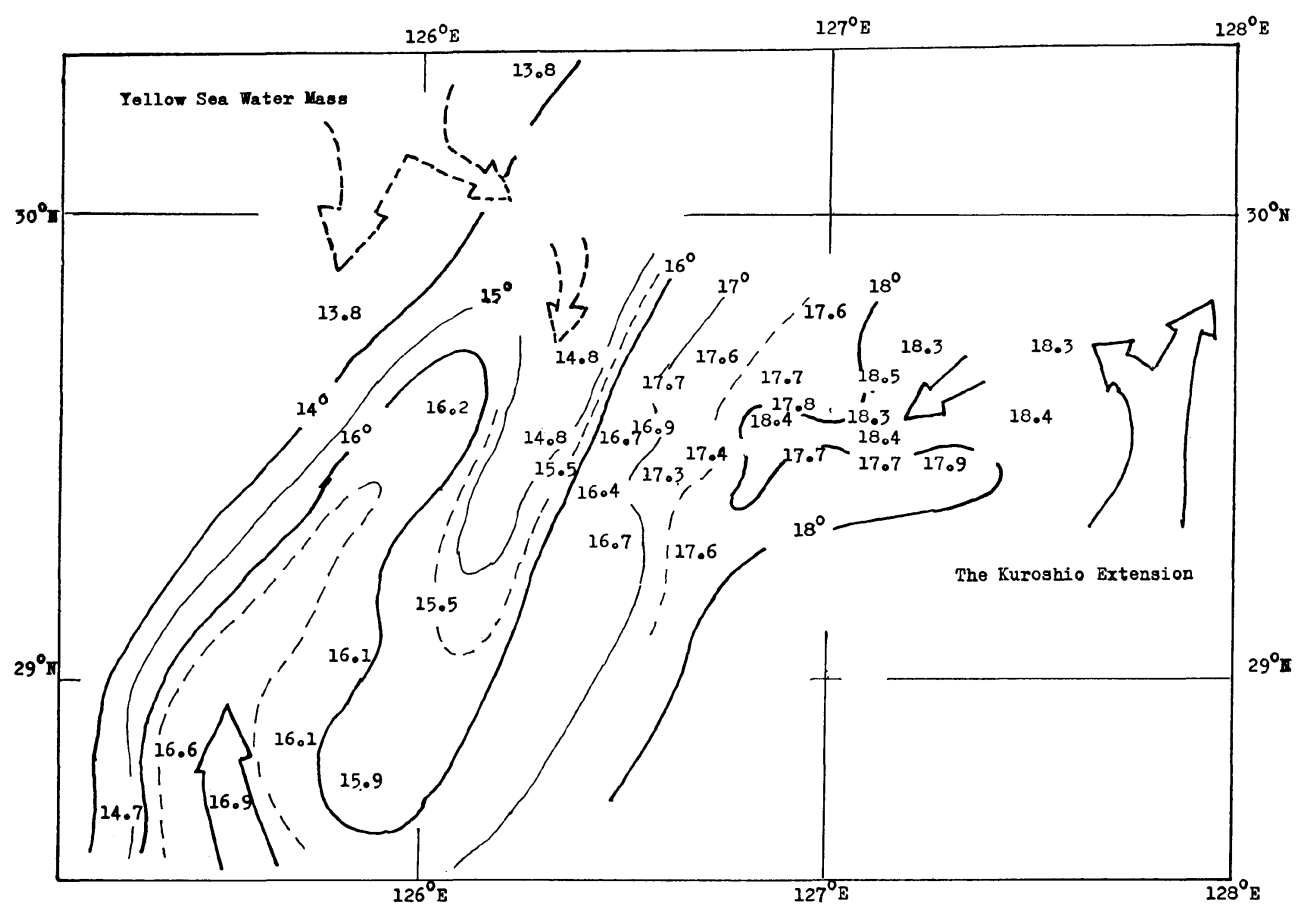

Fig. 3. Map showing the distribution of sea surface temperatures with isotherms $\left({ }^{\circ} \mathrm{C}\right)$. 


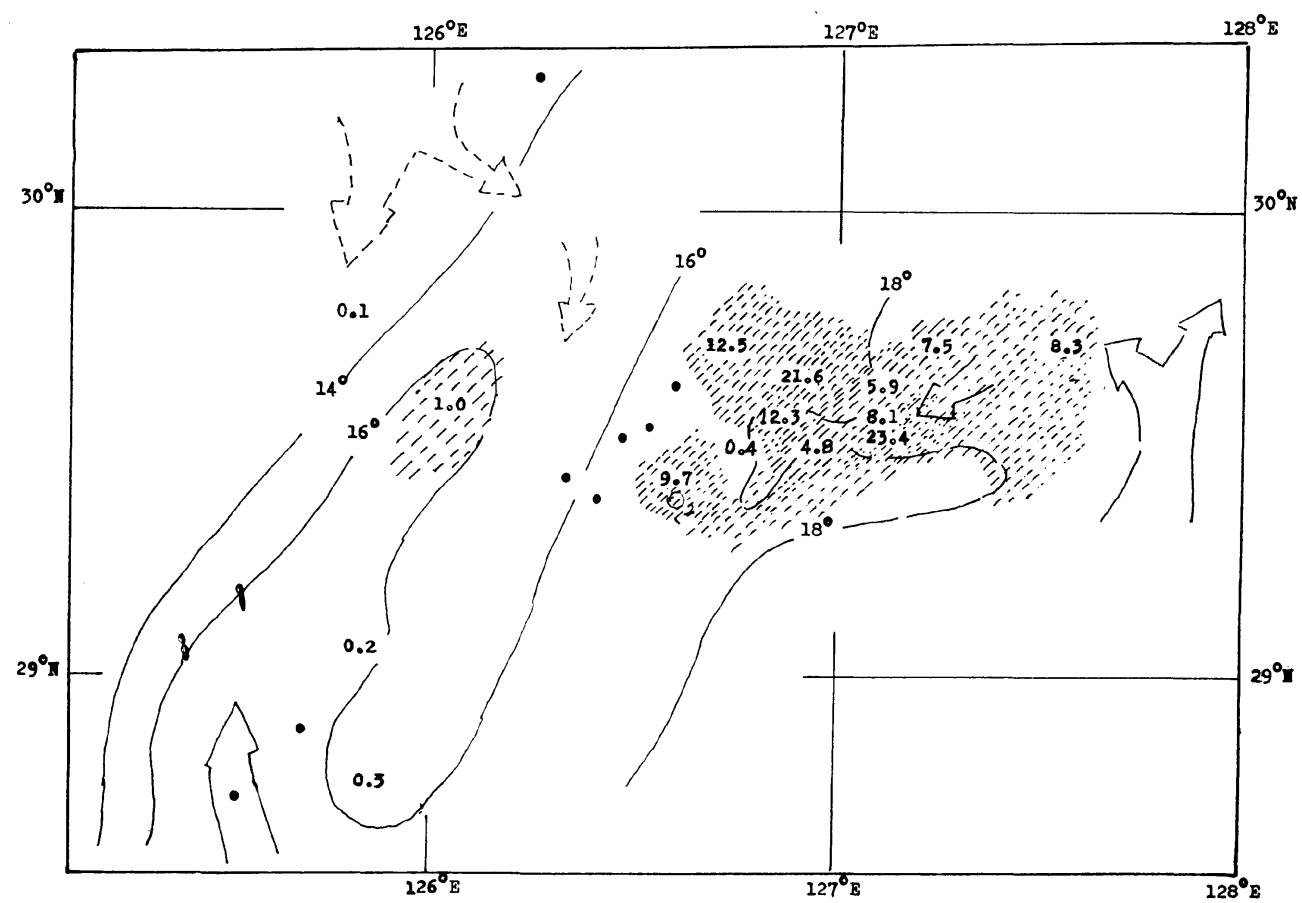

Fig. 4. Map showing the numericad distribution o fStreaked Shearwater. Numbers indicate average no. of birds per one sighting.

cold water where the temperature was of $14^{\circ} \mathrm{C}$ level.

Fig. 4 shows the numerical distribution of Streaked Shearwater expressed by anverage numbers per one sighting.

Table 2 shows the average numbers per one sighting of Streaked Shearwater and Red-necked Phalarope in relation to the surface temperatures.

Numerical distribution of Red-necked Phalarope is shown on the isotherm sheet in Fig. 5.

Table 2. Average numbers of Streaked Shearwater and Red-necked Phalarope in relation to surface temperatures.

\begin{tabular}{|c|c|c|c|c|c|c|c|}
\hline \multirow{2}{*}{$\begin{array}{c}\text { Temp. } 0 \mathrm{~m} \\
\left({ }^{\circ} \mathrm{C}\right)\end{array}$} & \multirow{2}{*}{$\begin{array}{l}\text { Obsed } \\
\text { freq. } \\
\quad \mathrm{f}\end{array}$} & \multicolumn{3}{|c|}{ Streaked Shearwater } & \multicolumn{3}{|c|}{ Red-necked Phalarope } \\
\hline & & $\begin{array}{c}\text { Numbers } \\
\mathrm{n}\end{array}$ & $\begin{array}{c}\text { Average } \\
\mathrm{n} / \mathrm{f}\end{array}$ & Pooled & $\begin{array}{c}\text { Numbers } \\
\mathbf{n}\end{array}$ & $\begin{array}{c}\text { Average } \\
\mathrm{n} / \mathrm{f}\end{array}$ & Pooled \\
\hline 13 & 10 & 1 & $0.1\}$ & \multirow{2}{*}{0.1} & 348 & $34.8\}$ & \multirow{2}{*}{34.8} \\
\hline 14 & - & - & \} & & - & - $\}$ & \\
\hline 15 & 16 & 2 & $0.2\}$ & \multirow{2}{*}{2.0} & 180 & 11.3 & \multirow{2}{*}{9.0} \\
\hline 16 & 44 & 9 & $1.9\}$ & & 361 & $8.2\}$ & \\
\hline 17 & 40 & 285 & $7.2\}$ & \multirow{2}{*}{9.4} & 160 & $4.0\}$ & \multirow{2}{*}{2.0} \\
\hline \multirow[t]{2}{*}{18} & 40 & 465 & $10.6\}$ & & 2 & $0.1\}$ & \\
\hline & 150 & 762 & 5.08 & & 1051 & 7.01 & \\
\hline
\end{tabular}




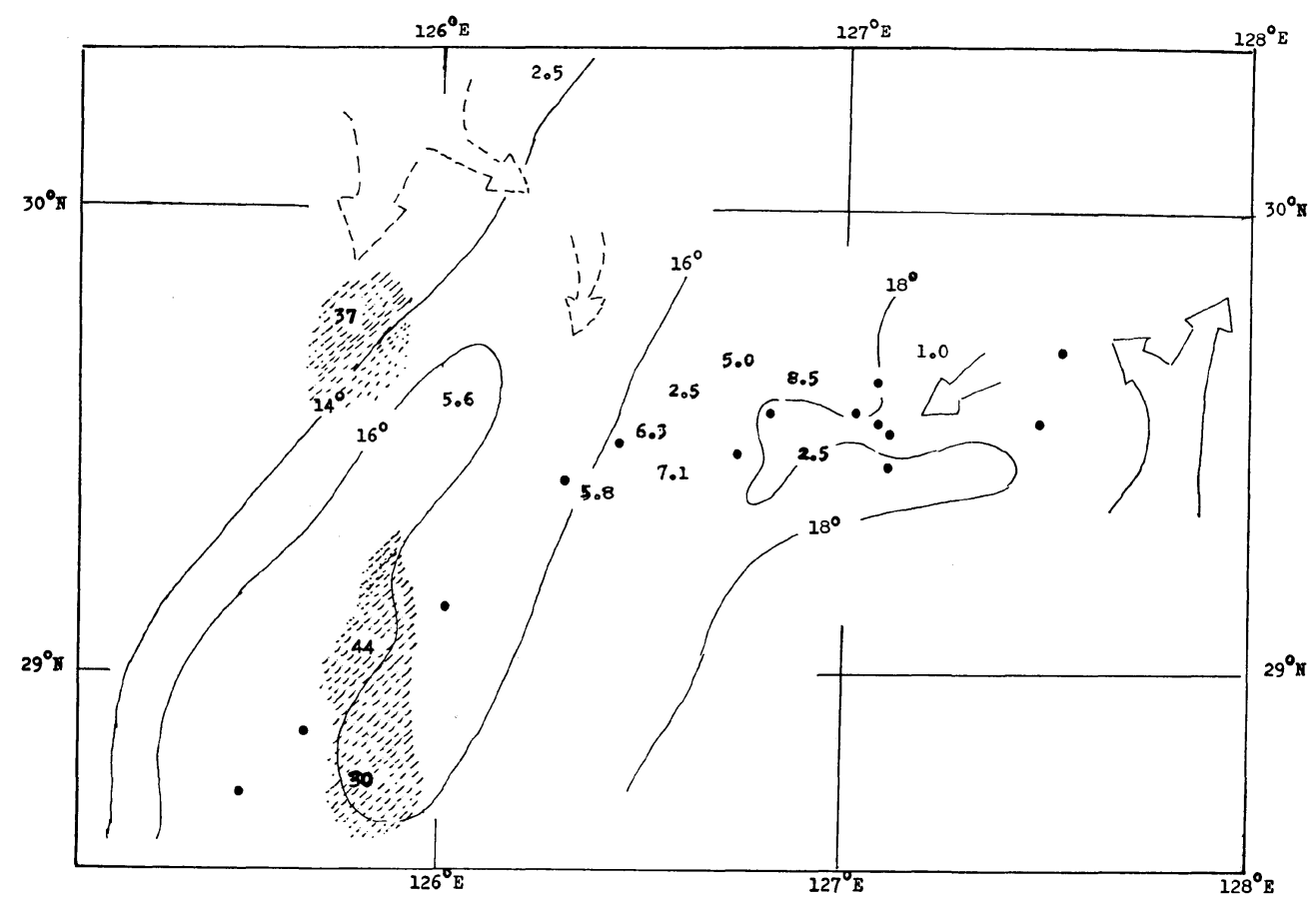

Fig. 5. Map showing the distribution of Red-necked Phalarope.

According to the above records, there were differences of distributions; the Streaked Shearwater was observed in the warm water of the Kuroshio extension, whereas the Phalarope was in the colder sea influenced by the Yellow Sea water. However, concentration around "tide rips", that were formed by these two water masses was clearly recognized. Phalarope is, particularly, known as dweller along tide rips.

3. House Swallow in relation to wether conditions.

As mentioned previously, House Swallow was observed at midway over the East China Sea in early-April. But, according to the biological calender (1970), the first bird of this species has been seen in southern Kyushu already on around March 18 and in Tokyo area in mid-April. The occurrence of the Swallow in relation to weather condition and wind directions, etc. are shown in the following tables (Table. 3 8).

From Table 3, there can be noticed no correlation of cloud area with the occurrence of the Swallows.

Wind direction in the area varys depending mainly on cold front generaly moving east-north-eastward. In the north of this front, blew the northeasterly wind and the air temperature fell as low as to $12^{\circ} \mathrm{C}$. When the front passed north, the southerly wind prevailed, raising the temperature as high as to $19^{\circ} \mathrm{C}$. Table 4 shows wind directions in relation to air temperatures and average numbers of House Swallow. In Fig. 6 are shown the above relations, indicating that the calculated mean wind direction being $77^{\circ}$ in true. 
Table 3 Numbers of House Swallow sighted in relation to weather condition-Cloud Area-.

\begin{tabular}{c|c|ccc}
\hline $\begin{array}{c}\text { Weather } \\
\text { condition }\end{array}$ & $\begin{array}{c}\text { Cloud } \\
\text { area }\end{array}$ & $\begin{array}{c}\text { Obsed } \\
\text { freq. } \\
\mathrm{f}\end{array}$ & $\begin{array}{c}\text { Numbers } \\
\text { counted } \\
\mathrm{n}\end{array}$ & $\begin{array}{c}\text { Average } \\
\text { number } \\
\mathrm{n} / \mathrm{f}\end{array}$ \\
\hline $\mathrm{b}$ & 0.5 & 52 & 37 & 0.73 \\
$\mathrm{bc}$ & 4.5 & 39 & 2 & 0.05 \\
$\mathrm{c}$ & 7.5 & 17 & 13 & 0.76 \\
$\mathrm{o}$ & 9.5 & $42^{*}$ & $84^{*}$ & $2.00^{*}$ \\
& & 41 & 34 & 0.83 \\
\hline & & $150^{*}$ & $136^{*}$ & $0.91^{*}$ \\
\hline
\end{tabular}

* These numbers include the occurrence of 50 birds at one sighting.

Table 4 Air temperature and numbers of House Swallow in relation to wind directions.

\begin{tabular}{c|cccccccc|c}
\hline $\begin{array}{c}\text { Air } \\
\text { temp }\end{array}$ & \multicolumn{7}{|c|}{ Wind direction (four-hourly) } & \multirow{2}{*}{ Total } \\
\hline 19 & $\mathrm{~N}$ & $\mathrm{NE}$ & $\mathrm{E}$ & $\mathrm{SE}$ & $\mathrm{S}$ & $\mathrm{SW}$ & $\mathrm{W}$ & $\mathrm{NW}$ & \\
\hline 18 & & & & 2 & 1 & & & & 3 \\
17 & 1 & 1 & 1 & 1 & 1 & 2 & & & 11 \\
16 & 1 & 2 & & & 2 & & & & 7 \\
15 & 5 & 1 & & & & 1 & & & 5 \\
14 & 2 & & & & & & & 1 & 3 \\
13 & 4 & 1 & & & & & & 1 & 6 \\
12 & 3 & 1 & & & & & 1 & & 5 \\
\hline Obs. f. & 49.5 & 27.5 & 20 & 38 & 10 & - & - & 5 & 150 \\
\hline $\mathrm{n}$ & 46 & 25 & 11.5 & $52.7^{*}$ & 0 & - & - & 1 & 136 \\
\hline$\overline{\mathrm{n}}$ & 0.93 & 0.91 & 0.58 & $1.45^{*}$ & 0 & - & - & 0.20 & 0.91 \\
\hline
\end{tabular}

Observed frequencies and numbers of the birds ranged between two of the above 8 points are divided to each of the nearest two points.

* includes 50 birds occurred at one sighting.

The westerly wind brings the coldest temperature, because of the existence of cold water mass prevailing in the west as shown in Fig. 3.

House Swallows were observed when the winds blew between W. N. W. and S. S. E., and the largest number occurred with N. N. E. winds. From these observetions the birds flying northwards may have been halted their advance by against winds and flew around the ship or came into her.

However, a flock of 50 birds flew by the ship at $0800 \mathrm{hrs}$, April 7, with the south-easterly winds which were favorable for their movement. Swallow and other land-birds occurred around the ship under two conditions: birds were exhausted and came in the ship, particularly, when it was raining or shortly after rainfalls, 


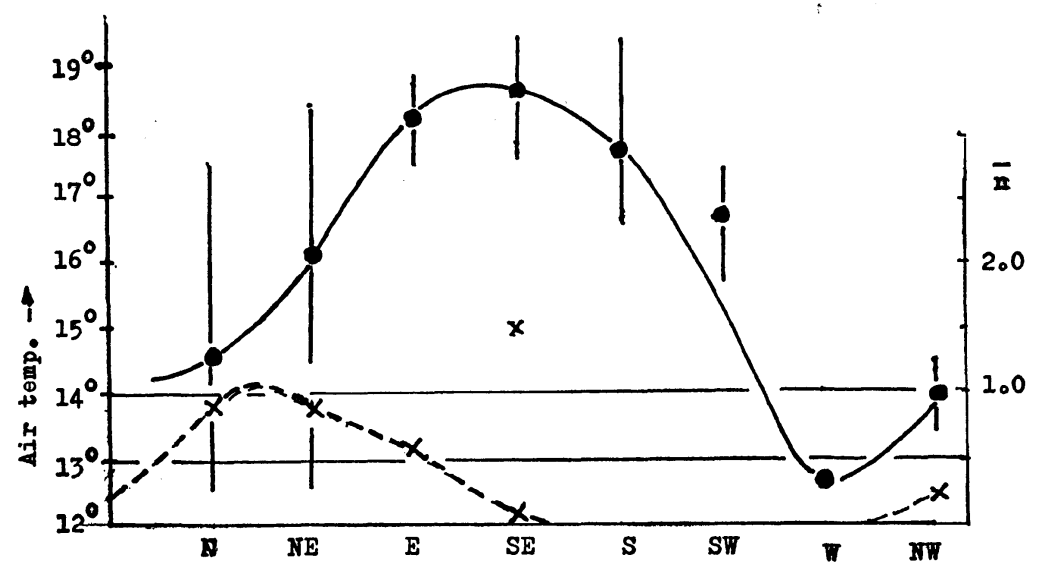

Fig. 6. Showing air temperature in ralation to wind direction and average number of House Swallow.

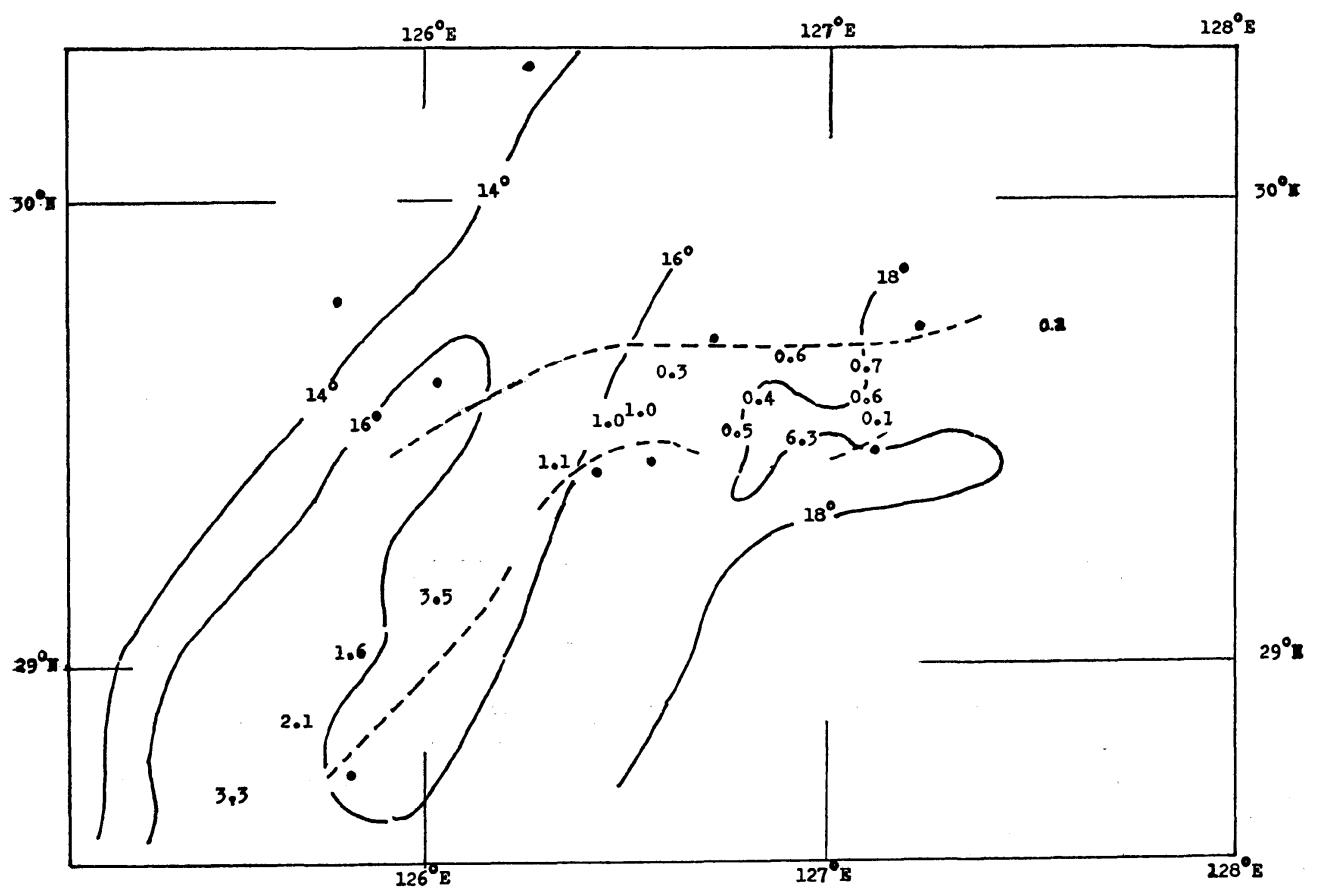

Fig. 7. Map showing the numerical distribution of House Swallow and the limits of occurrence (Dotted lines)

but they flew on passing beside the ship with southerly winds.

Fig. 7 indicates the numerical distribution of the House Swallow, the dotted lines showing a rough demarcation of its occurrence area. They were recorded over warmer waters than $14^{\circ} \mathrm{C}$ of the surface temperature. Conclusively, the Swallows would migrated along the western margin of the Kuroshio that is the western 
extremity of the migratory route in this season.

4. Distribution of other land-bird.

Land-dirds encountered during the cruise are shown in Fig. 8. Their occurrence pattern was similar to that of the House Swallow in relation to the surface temperature.

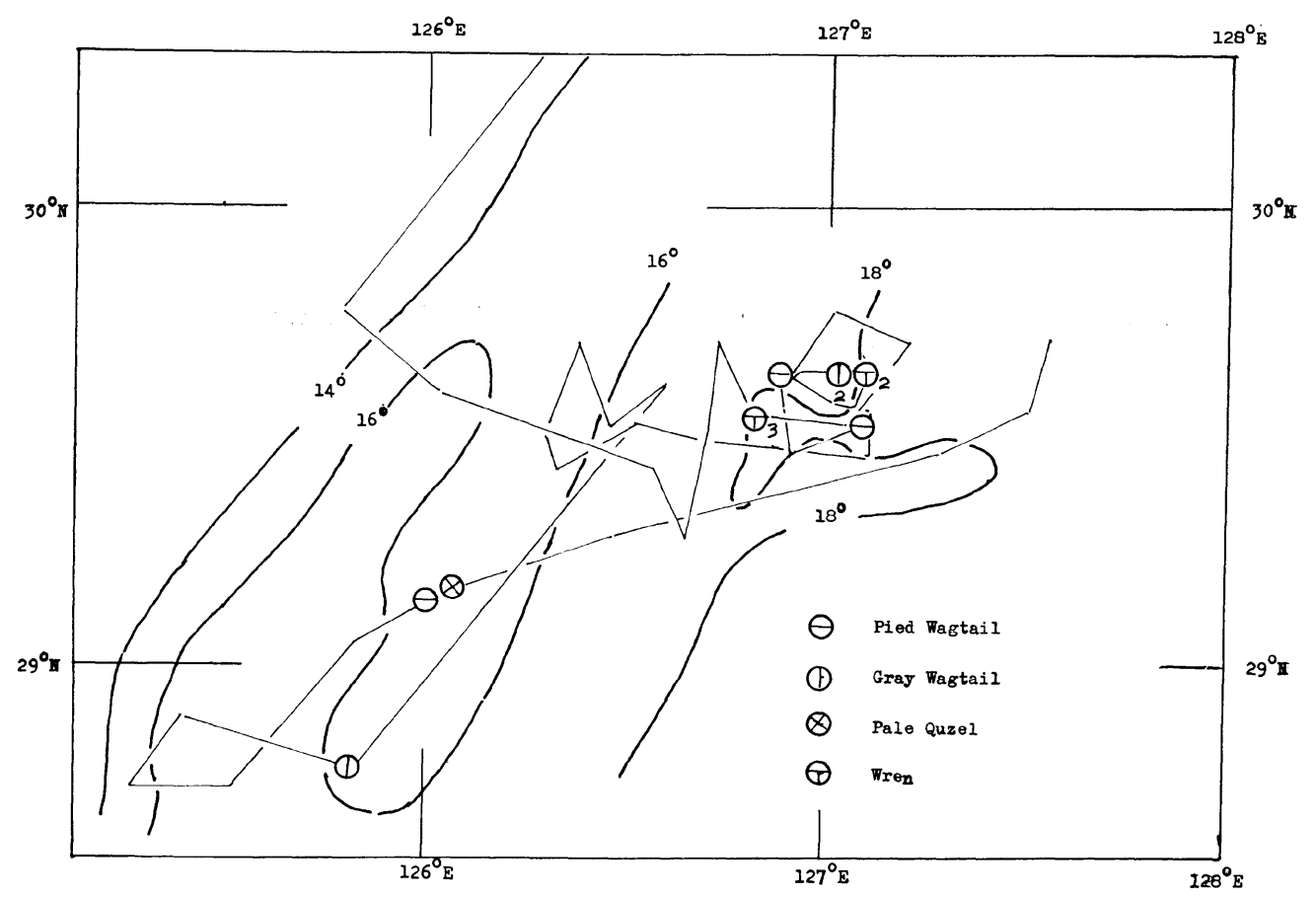

Fig. 8. Map showing location of occurrence of land-birds, except House Swallow.

\section{SUMMARY}

1. During the 32nd training cruise of the "Umitaka Maru" in the East China Sea in early April, 1968, bird observations were made by the author and his assistants.

2. A total of 150 sightings were made half-hourly in the daytime from $1600 \mathrm{hrs}$, April 2 to 2000 hrs, April 8, 1968.

3. Five species of sea-birds, Streaked Shearwater, Red-necked Phalarope, Pink-footed Sheawater, Pomarine Skua and Gull, and five species of land-birds, House Swallow, Pied Wagtail, Pale Ouzel and Wren were sighted.

4. Streaked Shearwater distributed mainly in the warm waters of the Kuroshio stream, whereas Red-necked Phalarope in rather colder waters of the Yellow Sea water mass. Both species were observed in larger numbers around "tide rips" formed by the two water masses.

5. The numbers of House Swallow seen around the ship seem to have nothing to do with area of clouds. The exhausted ones, in general, came into the ship with the northerly winds and rain. The western extremity of their migratory route seemed to be demarcated by the western margin of the Kuroshio. 


\section{Reference :}

Uchida, S. 1957 "Encyclopedia Zoologia Illustrated in Colours", Vol. I., Hokuryu-Kan Pub, Co., Tokyo. pp. 93-216.

Tokyo Astronomical Observatory 1970. RIKA NEMPYO (Anuual Calender of Science), The Maruzen Co., Tokyo.

\section{8年 4 月，海鷹丸による東支那海における鳥類の観察}

\section{小 沢 敬 次 郎}

1968年 4 月 2 日から 8 日にわたり, 東京水産大学練習船海鷹丸は東支那海中央部の北緯 $28^{\circ} 40^{\prime}-30^{\circ} 15^{\prime}$, 東経 $125^{\circ}-128^{\circ}$ に围まれた海域で行動中, 鳥類の観察をおこなった。観察された鳥種は才オミズナギド リ，アカアシミズナギドリ，トウゾクカモメ，アカエリヒレアシシギ持よびカモメ類 5 種の海鳥とツバ メ，八クセキレイ，キセキレイ，ミソサザイ，シロハラの 5 種の陸鳥であった。

観察は日の出から日没の間, 毎30分に見られる鳥種とその数を数え, 目視観察野帖に記録した。総観察 度数は150 回であった。

オオミズナギドリとアカエリヒレアシシギにつんて水塊に対する分布を考察し, 前者は黒潮系温水域 に, 後者はむしろ黄海冷水域の外縁に多々とした。ツバメと天候, 雲量との関連を求めたが明瞭な結果は 得られず, ツバメの分布は黒潮流域にむしろ多く, 渡りも黑潮流域に沿って行われるよらである。

（東京水産大学, 海鷹丸)

\section{折居彪二郎氏の死去}

山階鳥類研究所の採集者として多年内外各地の鳥類・哺乳類・蝶類の採集に従事した折居㓳二郎 君が1970年 4 月 27 日北海道苫牧市植苗の自宅にて逝去された。享年87歳。氏は 1906 年に Malcom Anderson と共に朝鮮に採集旅行をしたのが始めで，1936年の大東島採集迄30年間を学術標本採集 につくし，その間1926年から1936年迄の10年間の採集品は全部山階鳥類研究所に保存されて居る。 氏の業績につ々ては「鳥」第12巻57号（1948）に詳記されているので，てれを参照されたい。 ととに謹んで同君の死去を哀悼する。 